Journal of Educational

Technology \& Online Learning

Volume 4 | Issue $4 \mid 2021$

http://dergipark.org.tr/jetol

\title{
Examination of classroom teachers' technological pedagogical content knowledge and teacher self-efficacy beliefs
}

\author{
Tuğçe KAŞCI ${ }^{\text {* }}$ (D), Gülenaz SELÇUK ${ }^{\text {b (D) }}$ \\ ${ }^{a}$ M.E.B., Turkey \\ b Manisa Celal Bayar University, Turkey
}

Suggested citation: Kaşçı, T. \& Selçuk, G. (2021). Examination of classroom teachers' technological pedagogical content knowledge and teacher self-efficacy beliefs. Journal of Educational Technology \& Online Learning, 4(4), 774-792.

\begin{tabular}{|c|c|}
\hline Article Info & Abstract \\
\hline $\begin{array}{l}\text { Keywords: } \\
\text { Technological pedagogical } \\
\text { content knowledge } \\
\text { TPACK } \\
\text { Self-efficacy beliefs } \\
\text { Teachers }\end{array}$ & $\begin{array}{l}\text { This study aims to examine classroom teachers' technological pedagogical content } \\
\text { knowledge and classroom teachers' self-efficacy beliefs. The research was conducted in } \\
\text { the correlational research model, one of the general survey models. The sample of the } \\
\text { research consisted of } 1127 \text { classroom teachers working in } 150 \text { primary schools affiliated } \\
\text { with the Manisa Provincial Directorate of National Education in the } 2020-2021 \text { academic } \\
\text { year. The research data were collected using online data collection tools consisting of } \\
\text { three parts. "Technological Pedagogical Content Knowledge Scale for Classroom } \\
\text { Teachers" and "Teacher Self-Efficacy Scale" were used as data collection tools. } \\
\text { Descriptive statistics, ANOVA, Kruskal Wallis H Test and Pearson Correlation analyses } \\
\text { were used in the analysis of the data. The results of the research showed that classroom } \\
\text { teachers' technological pedagogical content knowledge and self-efficacy beliefs were at } \\
\text { a high level. It was determined that the technological pedagogical content knowledge of } \\
\text { classroom teachers showed statistically significant differences according to the variables } \\
\text { of the duration of computer technology usage and the duration of mobile technology } \\
\text { usage, and it was determined that there was no statistically significant difference in terms } \\
\text { of gender and professional seniority variables. Teacher self-efficacy levels of classroom } \\
\text { teachers showed a statistically significant difference in terms of professional seniority, } \\
\text { duration of use of computer technologies and duration of mobile technologies, but there } \\
\text { was no significant difference in terms of gender. Finally, with Pearson Correlation } \\
\text { Analysis, it was concluded that there was a high level of a positive and significant } \\
\text { relationship between classroom teachers' technological pedagogical content knowledge } \\
\text { and teacher self-efficacy beliefs. }\end{array}$ \\
\hline Research Article & fs. \\
\hline
\end{tabular}

\section{Introduction}

The development process in the $21^{\text {st }}$ century has affected societies in many areas, and humanity has entered a rapid change process depending on these developments. These developments in technology have affected society in every field as well as in the field of education. Education has lost its classical teachings in today's world and has changed. In the $21^{\text {st }}$ century, education has become a process that aims to know, produce, increase knowledge, and learn continuously (Çelebi, 2016). Being able to raise entrepreneurial individuals who know and research the ways of accessing information through education, can use technology

\footnotetext{
* Corresponding author: M.E.B., Turkey.

e-mail address: tugcekasci@outlook.com

This study was produced from Tuğçe Kaşcı's MA thesis entitled "Examination of Classroom Teachers' Technological Pedagogical Content Knowledge and Teacher Self-Efficacy Beliefs" conducted under the consultancy of Asst. Prof. Dr. Gülenaz Selçuk.

This study was also partly presented as a proceeding at the 1st International Conference on Educational Technology and Online Learning Conference held between 22-24 September 2021.
} 
effectively and efficiently, question and think critically, are open to development and change, can follow innovations and apply them in their lives, keep up with the rapid changes in the information society and turn these changes into opportunities comes to the fore (Değirmenci, 2014). The way to train individuals with the equipment required by the age is to use technology effectively in education by following the innovations and developments in information and communication technologies in the journey of learning and teaching.

Investments specific to the use of technology in education are increasing day by day in Turkey. The FATIH Project, the EBA platform, studies carried out in line with the 2023 education vision, equipping classrooms with technological tools and equipment, improving, and updating the technological infrastructure, establishment of various online learning platforms are developments that lead to widespread and effective use of technology in education. However, investing solely in technology is not an adequate solution to train well-equipped individuals required by the age is not an adequate solution to train valid chipped individuals required by the age. When the technological and physical infrastructure are not combined with the power of the teacher, they are not made use of to their fullest potential (MEB, 2018). The way to integrate technology into education and teaching is through teachers' having the required knowledge, skills, and qualifications (Akkoç \& İmre, 2015). It is thought that for technology integration, teachers should be trained to use technology effectively in learning and teaching processes in the light of the innovations brought by the digital age (Önal, 2019). This situation imposes new responsibilities and competencies on teachers in the professional sense. When the General Competencies Document for the Teaching Profession (2017) was examined, it was seen that pedagogical content knowledge was emphasised within the scope of professional knowledge and professional skill competence. Today, having pedagogy and field knowledge is not an indicator of being an adequate teacher (Bilici \& Yadigaroğlu, 2018). While teachers are required to have pedagogical and content knowledge, they are also expected to have technological knowledge today (Akgün \& Karadeniz, 2013).

Teachers need to believe in their own competencies and self-confidence so that they can demonstrate the performance expected of them, be motivated, and make the necessary self-regulations. At this point, the role of teacher self-efficacy beliefs comes into play. From this point of view, it is thought that considering and discussing self-efficacy belief and Technological Pedagogical Content Knowledge (TPACK) together will contribute significantly to the field.

\section{Literature}

\subsection{TPACK}

Mishra and Koehler (2006) defined the TPACK model as three intersecting circles that show the interrelationships between the components of Technological Knowledge (TK), Pedagogical Knowledge (PK), and Content Knowledge (CK). TPACK, located at the intersection of three knowledge and in a dynamic and functional interaction with all three components (Figure 1), is a unique type of knowledge.

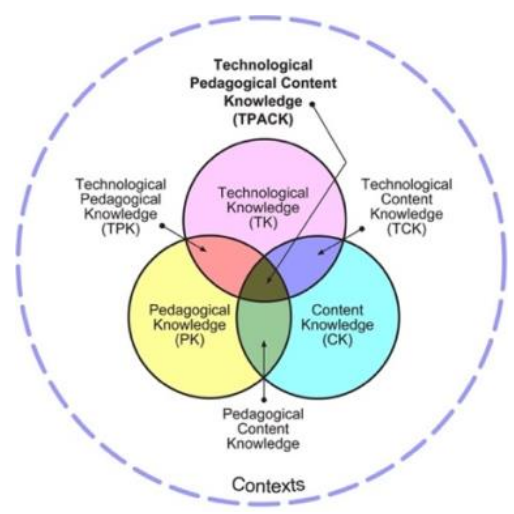

Figure 1. The Components of TPACK (Mishra \& Koehler, 2009) 
$T K$ : It is the knowledge of standard technologies. It is the ability to learn, adapt to new technologies and use materials ranging from old technologies such as books, overhead projectors to more advanced technologies such as interactive books, smart boards, internet, virtual learning environments (Mishra \& Koehler, 2006; Mishra \& Koehler, 2009; Koehler et al., 2013).

CK: It was defined by Shulman (1987) as knowledge about standard concepts and facts of a subject. In other words, content knowledge is the main information and basic concepts related to the subject to be taught or learned.

$P K$ : It is the activity of motivating students, making sense and scaffolding between students and controlling understanding (Angeli \& Valanides, 2005). In general, PK includes instructional practices, knowledge of learning processes and strategies, classroom management skills, and a teacher's knowledge of their students.

PCK: It is the knowledge of using the most appropriate teaching methods, examples, explanations and analogies (Shulman, 1986).

TPK: Koehler and Mishra (2008) defined TPK as the knowledge of understanding how the use of educational technologies in education transforms teaching-learning environments and how technology can support certain pedagogical goals and learning goals.

TCK: It is the type of knowledge that arises from the combination of TK and CK. Teachers should have a good command of the content knowledge and should be able to determine and choose which educational technology will be appropriate while transferring the content knowledge to the students, as well as be able to use the technology with which they can carry out teaching activities efficiently (Koehler et al., 2013).

TPACK: It is a type of information that arises from the combination of PK and CK. Mishra and Koehler (2008) defined TPACK as the knowledge of how technology can be used to better understand the content represented by the concepts and to teach CK in a constructivist pattern using other methods, to understand students' conceptual confusion using technology, to develop new knowledge theories of students or to strengthen their knowledge theories. TPACK is a type of knowledge that an individual has or lacks, and basically, as a competency formed by teacher actions in a teaching situation (Willermark, 2018)

\subsection{Self-Efficacy Beliefs}

According to Bandura (1977), self-efficacy belief is the belief that an individual has in their ability to organise and successfully perform the activities they need to realize performance. Self-efficacy beliefs not only constitute a significant part of individuals' motivation and behaviors, but they can also change behaviours that can point someone's life in a direction (Koç \& Bursal, 2016). An individual's perception as to what they can achieve determines their behaviour. Beliefs about self-efficacy affect how an individual thinks, how an individual feels, and how an individual behaves (Zimmerman, 2000). While an individual's perception of their capacity as lower than it is may prevent them from using their ability in the best way, an individual's perception of their capacity as greater than it is may contribute positively to the individual's performance (Tschannen-Moran et al., 1998).

\subsection{Teachers' Self-Efficacy Beliefs}

Teacher self-efficacy belief is one of the factors affecting teachers' professional success. The professional achievements of teachers depend on their belief that they have professional competencies, that they can use these competencies effectively and that they can fulfill their duties (Y1lmaz et al., 2004). Teacher selfefficacy belief plays a decisive role in seeing the professional determination of teachers and determining the results they can get from them (Aslan \& Kalkan, 2018).

Teachers' self-efficacy belief is a driving force that affects professional determination, teachers' in-class behaviors and perseverance and patience in the educational process. Teacher self-efficacy belief, which is a supporting power, is important for the effectiveness of education and training activities (Klassen et al., 2009; Klassen Tze, 2014). 
While teachers with high self-efficacy beliefs can provide self-sufficient motivation in the teaching process and transfer this to their students, teachers with low self-efficacy beliefs may experience decreases in their abilities that will directly affect their teaching behaviors (Kandemir, 2015). It can be deduced that teachers with low self-efficacy beliefs may not be able to use their knowledge and skills effectively in the education process, and teachers with high self-efficacy beliefs but lacking in knowledge and skills can manage the education and training process well. A teacher's ability to manage the educational process well is one of the indicators of their success. The success or failure of the teacher in the education process is directly related to the teacher's self-efficacy belief (Kaçar \& Beycioğlu, 2017).

\subsection{The Relationship between TPACK and Teachers' Self-Efficacy Belief}

It is apparent that the use of technology in the education process is more efficient and beneficial for students and teachers, and the use of technology is now a necessity for a successful educational process. However, the use of technology in education does not always mean the education is successful. Because there are many different obstacles in the realization of technology integration in education. The obstacles in the technology integration are listed as: "(1) state of hardware and network infrastructure, (2) support, (3) education level of the teacher, (4) perceptions and attitudes," and "(5) time and heavy teaching load (Arslan \& Şendurur, 2017). Ertmer (2005) states that in technology integration, external factors such as hardware and software can easily be controlled, but internal factors directly related to the teacher are important obstacles that cannot be changed easily. At this point, it can be said that the education level, perceptions, and attitudes of the teacher are important factors in technology integration. Teachers' TPACKs are one of the internal factors that play a key role in technology integration (Y1lmaz, 2015). Another internal factor affecting the teacher's in-class behavior and motivation is the teacher's self-efficacy belief. These two internal factors directly affect the teacher in technology integration.

Increasing only the TPACK of teachers in technology integration in education is not an indication that education will be carried out at the desired level. Because the professional success of the teacher cannot be considered independently of the teacher's self-efficacy belief. Teachers with low self-efficacy may not be able to use these skills effectively, even if they have a high TPACK. Therefore, it would be beneficial for a successful teacher to have both these skills at a high level in the technology integration process.

\subsection{Aim of the Study}

This research aims to examine the technological pedagogical content knowledge of classroom teachers and their self-efficacy beliefs. Answers to the following questions were sought.

1. What is the level of TPACK of classroom teachers?

2. What is the level of teacher self-efficacy beliefs of the classroom teachers?

3. Do the TPACK of classroom teachers show statistically significant differences according to gender, professional seniority, duration of use of computer technologies, duration of use of mobile technologies variables?

4. Do the self-efficacy beliefs of classroom teachers show a statistically significant difference according to the professional seniority, duration of use of computer technologies, and duration of use of mobile technology variables?

5. Is there a significant relationship between classroom teachers' TPACK and teacher self-efficacy beliefs? 


\section{Methodology}

\subsection{Research Design}

The research was carried out using the correlational research model, one of the general survey models. The correlational research model that is aims to determine whether there is a change between two or more variables and if there is a change, to what extent the change is (Karasar, 2008).

\subsection{Data Collecting Tools}

The research data was collected online using a data collection tool consisting of three parts via Google form. The first section includes the demographic variables, the second section includes the "TPACK Scale for Classroom Teachers" and the third section includes the "Teacher Self-Efficacy Belief Scale".

\subsubsection{TPACK Scale for Classroom Teachers}

The "TPACK Scale for Classroom Teachers", which consists of 46 items developed by Kaya and Dağ (2013), was used to determine the TPACK of classroom teachers. The scale items in the five-point Likert form are scored as "I strongly disagree (1)", "I disagree (2)", "Undecided (3)", "I agree (4)" and "I strongly agree (5)". In this study, the Cronbach Alpha reliability coefficient for the entire scale was found as 0.97.

\subsubsection{Teacher Self-Efficacy Belief Scale}

To determine teachers' self-efficacy belief levels, "the Teacher Self-Efficacy Scale" consisting of 27 items developed by Çolak et al. (2017) was used. The scale items in the five-point Likert form are scored as "I strongly disagree (1)", "I disagree (2)", "Undecided (3)", "I agree (4)" and "I strongly agree (5)". In this study, the Cronbach Alpha reliability coefficient for the entire scale was found as 0.96 .

\subsection{Sampling or Study Group}

The sample of the research consisted of 1127 classroom teachers working in 150 primary schools affiliated with the Manisa Provincial Directorate of National Education in the 2020-2021 academic year. The stratified sampling method was used while determining the sample of the study. It is a type of sampling that aims to represent the subgroups of the population in the sample by determining their proportions in the size of the population (Büyüköztürk et al., 2020).

Since it was not possible to reach all the teachers in the research population, it was decided that 1127 people were sufficient to sample with at a $98 \%$ confidence level and a 3\% margin of error, using the known sample formula. The research represents $33 \%$ of the population.

\subsection{Data Analysis}

In the study, the data obtained from 1127 classroom teachers were analysed using the Statistical Package for the Social Sciences (SPSS) 26.0 program. The frequency and percentage distribution of the demographic characteristics of the participants participating in the research were calculated. In the first and second subproblems of the research, the descriptive statistics method was used, and the findings were presented in a table. Levene's homogeneity test was applied to determine which parametric/nonparametric test would be used in the third and fourth sub-problems of the research. T-Test and one-way analysis of variance (ANOVA) were used for normally distributed data, and Kruskal Wallis H Test and Post Hoc (LSD) tests were used for data that did not show normal distribution. Pearson Correlation Analysis was conducted to find an answer to the fifth sub-problem of the research. 
Table 1. The Frequency Analysis of the Demographic Characteristics of Classroom Teachers Participating in the Research

\begin{tabular}{|c|c|c|c|}
\hline Demographic Characteristics & Variables & $\mathbf{F}$ & $\%$ \\
\hline \multirow[t]{2}{*}{ Gender } & Female & 685 & 60.8 \\
\hline & Male & 442 & 39.2 \\
\hline \multirow[t]{6}{*}{ Professional Seniority } & $1-5$ years & 59 & 5.2 \\
\hline & $5-10$ years & 119 & 10.6 \\
\hline & $10-15$ years & 218 & 19.3 \\
\hline & $15-20$ years & 190 & 16.9 \\
\hline & 20 years or more & 541 & 48.0 \\
\hline & $1-5$ years & 16 & 1.4 \\
\hline \multirow{4}{*}{ Duration of Use of Computer Technologies } & $5-10$ years & 123 & 10.9 \\
\hline & $10-15$ years & 363 & 32.2 \\
\hline & $15-20$ years & 404 & 35.8 \\
\hline & 20 years or more & 221 & 19.6 \\
\hline \multirow[t]{5}{*}{ Duration of Use of Mobile Technologies } & $1-5$ years & 79 & 7.0 \\
\hline & $5-10$ years & 297 & 26.4 \\
\hline & $10-15$ years & 351 & 31.1 \\
\hline & $15-20$ years & 276 & 24.5 \\
\hline & 20 years or more & 124 & 11.0 \\
\hline
\end{tabular}

\subsection{Findings}

\subsubsection{What is the level of TPACK of classroom teachers?}

The results of the analysis regarding the TPACK levels of classroom teachers are given in Table 2.

Table 2. TPACK Levels of Classroom Teachers

\begin{tabular}{lll}
\hline TPACK & $\bar{X}$ & ss \\
\hline TK & 3.85 & .94 \\
CK & 4.23 & .77 \\
PK & 4.60 & .54 \\
PCK & 4.52 & .60 \\
TCK & 4.42 & .67 \\
TPK & 4.31 & .72 \\
TPACK & 4.32 & .73 \\
\hline General & $\mathbf{4 . 3 2}$ & \\
\hline
\end{tabular}

Look at the findings in Table 2, it can be concluded that the level of TPACK of classroom teachers was high $(\overline{\mathrm{X}}=4.32)$. 


\subsubsection{What is the level of teacher self-efficacy beliefs of the classroom teachers?}

The results of the analysis regarding the teacher self-efficacy beliefs levels of classroom teachers are given in Table 3.

Table 3. Teacher Self-Efficacy Belief Levels of Classroom Teachers

\begin{tabular}{lll}
\hline TPACK & $\overline{\boldsymbol{X}}$ & SS \\
\hline Academic Self-Efficacy & 4.45 & .60 \\
Professional Self-Efficacy & 4.66 & .55 \\
Social Self-Efficacy & 4.50 & .59 \\
Intellectual Self-Efficacy & 4.21 & .81 \\
\hline General & $\mathbf{4 . 4 6}$ & \\
\hline
\end{tabular}

Looking at the findings in Table 3, it can be concluded that the teacher self-efficacy belief levels of the classroom teachers are high $(\overline{\mathrm{X}}=4.46)$.

3.5.3. Do the TPACK of classroom teachers show statistically significant differences according to gender, professional seniority, duration of use of computer technologies, duration of use of mobile technologies variables?

Table 4. T-Test Results of Classroom Teachers' TPACK Regarding Gender Variable

\begin{tabular}{llllllll}
\hline Dimension & Category & $\mathbf{N}$ & $\overline{\boldsymbol{X}}$ & sd & sd & t & p \\
\hline TPACK & Female & 685 & 4.29 & .50 & 1125 & -2.40 & .181 \\
& Male & 442 & 4.36 & .46 & & & \\
\hline
\end{tabular}

Within the scope of the independent sample t-test results in Table 4, there is no statistically significant difference in terms of the gender variable of classroom teachers' TPACK $(\mathrm{t}=-2.40, \mathrm{p}>0.05)$.

Table 5. ANOVA Test Results of Classroom Teachers' TPACK According to Professional Seniority Variable

\begin{tabular}{llllllll}
\hline Dimension & Category & $\mathbf{N}$ & $\overline{\boldsymbol{X}}$ & $\mathbf{s d}$ & $\mathbf{F}$ & $\mathbf{p}$ & Difference (LSD) \\
\hline TPACK & 1-5 years & 59 & 4.45 & .44 & 1.76 & .133 & - \\
& 5-10 years & 119 & 4.28 & .52 & & & \\
& 10-15 years & 218 & 4.28 & .49 & & & \\
& 15-20 years & 190 & 4.33 & .51 & & & \\
& 20 years or more & 541 & 4.32 & .47 & & & \\
& & & & & & & \\
\end{tabular}

According to the ANOVA results in Table 5, there is no statistically significant difference between classroom teachers' TPACK $(\mathrm{F}=1.76)$ and professional seniority variable $(\mathrm{p}>0.05)$. 
Table 6. Kruskal Wallis - H Test Results According to the Variable of TPACK of Classroom Teachers and the Duration of Use of Computer Technologies

\begin{tabular}{|c|c|c|c|c|c|c|c|}
\hline Dimension & Category & $\mathbf{N}$ & SO & sd & $\mathbf{X}^{2}$ & $\mathbf{p}$ & Difference (LSD) \\
\hline \multirow[t]{5}{*}{ TPACK } & $1-5$ years & 16 & 596.63 & 4 & 103.8 & .000 & \\
\hline & $5-10$ years & 123 & 397.11 & & & & $\begin{array}{l}\text { 5-10 Years }<10-15 \text { Years } \\
5-10 \text { Years }<15-20 \text { Years } \\
\text { 5-10 Years }<20 \text { Years or more }\end{array}$ \\
\hline & $10-15$ years & 363 & 498 & & & & $\begin{array}{l}10-15 \text { Years }<15-20 \text { Years } \\
10-15 \text { Years }<20 \text { Years or more }\end{array}$ \\
\hline & $15-20$ years & 404 & 584.17 & & & & $15-20$ Years $<20$ Years or more \\
\hline & 20 years or more & 221 & 726.06 & & & & \\
\hline
\end{tabular}

According to the results of Kruskal Wallis - H Test shown in Table 6, there is a statistically significant difference between classroom teachers' TPACK and the variable of using computer technologies $\left(\mathrm{X}^{2}\right.$ $=103.8, \mathrm{p}<0.05$ ). It was found out that classroom teachers who had been using computer technologies for 5-10 years had lower TPACK compared to classroom teachers who had been using computer technologies for 10-15 years, 15-20 years and 20 years or more, the classroom teachers who had been using computer technologies for 10-15 years had lower TPACK compared to classroom teachers who had been using computer technologies for 15-20 years and 20 years or more, the classroom teachers who had been using computer technologies for 20 years or more and the classroom teachers who had been using computer technologies for 15-20 years had lower TPACK than the classroom teachers who have been using computer technologies for 20 years or more.

Table 7. ANOVA Test Results of TPACK of Classroom Teachers According to Variable of Duration of Use of Mobile Technologies

\begin{tabular}{|c|c|c|c|c|c|c|c|}
\hline Dimension & Category & $\mathbf{N}$ & $\bar{X}$ & SS & $\mathbf{F}$ & p & Difference (LSD) \\
\hline \multirow[t]{5}{*}{ TPACK } & $1-5$ years & 79 & 4.04 & .49 & 17.14 & .000 & $\begin{array}{l}1-5 \text { Years }<5-10 \text { Years } \\
1-5 \text { Years }<10-15 \text { Years } \\
1-5 \text { Years }<15-20 \text { Years } \\
1-5 \text { Years }<20 \text { Years or } \\
\text { more }\end{array}$ \\
\hline & $5-10$ years & 297 & 4.23 & .47 & & & $\begin{array}{l}\text { 5-10 Years }<10-15 \text { Years } \\
\text { 5-10 Years }<15-20 \text { Years } \\
\text { 5-10 Years }<20 \text { Years or } \\
\text { more }\end{array}$ \\
\hline & $10-15$ years & 351 & 4.32 & .48 & & & $\begin{array}{l}10-15 \text { Years }<20 \text { Years or } \\
\text { more }\end{array}$ \\
\hline & $15-20$ years & 276 & 4.39 & .46 & & & $\begin{array}{l}15-20 \text { Years }<20 \text { Years or } \\
\text { more }\end{array}$ \\
\hline & 20 years or more & 124 & 4.53 & .45 & & & \\
\hline
\end{tabular}

According to the ANOVA results in Table 7, there is a statistically significant difference between classroom teachers' TPACK $(\mathrm{F}=17.14)$ and the variable of the duration of use of mobile technologies $(\mathrm{p}<0.05)$. It was found that this difference was against teachers who had been using mobile technologies between 1-5 years versus teachers who had been using mobile technologies between 5-10 years, 10-15 years, 15-20 years and 20 or more years; against teachers who had been using mobile technologies between 5-10 years versus 
teachers who had been using mobile technologies between 10-15,15-20 years and 20 years or more years, and in favour of the teachers who had been using mobile technologies for 20 or more years versus teachers who had been using mobile technologies for 10-15 years and 15-20 years.

3.5.4. Do the self-efficacy beliefs of classroom teachers show a statistically significant difference according to the professional seniority, duration of use of computer technologies, and duration of use of mobile technology variables?

Table 8. T-Test Results of Classroom Teachers' Teacher Self-Efficacy Beliefs Regarding the Gender

\begin{tabular}{llllllll}
\hline Dimension & Category & $\mathbf{N}$ & $\bar{X}$ & sd & sd & t & p \\
\hline Teacher Self-Efficacy Beliefs & Female & 685 & 4.45 & .49 & 1125 & .101 & .919 \\
& Male & 442 & 4.45 & .49 & & & \\
& & & & & & & \\
\hline
\end{tabular}

In Table 8, within the scope of t-test results, there is no statistically significant difference in terms of gender variable of classroom school teachers' teacher self-efficacy beliefs $(t=.101 \mathrm{p}>0.05)$.

Table 9. The Kruskal Wallis - H Test Results According to the Variable of Teacher Self-Efficacy Beliefs of Classroom Teachers and the Professional Seniority

\begin{tabular}{|c|c|c|c|c|c|c|c|}
\hline Dimension & Category & $\mathbf{N}$ & SO & sd & $\mathbf{X}^{2}$ & $\mathbf{p}$ & Difference (LSD) \\
\hline \multirow[t]{5}{*}{ Teacher Self-Efficacy Beliefs } & $1-5$ years & 59 & 4.53 & .41 & 3.16 & .013 & 1-5 Years $>5-10$ Years \\
\hline & $5-10$ years & 119 & 4.36 & .53 & & & $\begin{array}{l}\text { 5-10 Years }<15-20 \text { Years } \\
5-10 \text { Years }<20 \text { Years or } \\
\text { more }\end{array}$ \\
\hline & $10-15$ years & 218 & 4.38 & .52 & & & $\begin{array}{l}10-15 \text { Years }<15-20 \text { Years } \\
10-15 \text { Years }<20 \text { Years or } \\
\text { more }\end{array}$ \\
\hline & $15-20$ years & 190 & 4.51 & .46 & & & \\
\hline & 20 years or more & 541 & 4.47 & .48 & & & \\
\hline
\end{tabular}

According to the ANOVA test results in Table 9, there is a statistically significant difference between classroom teachers' self-efficacy beliefs $(\mathrm{F}=3.16)$ and professional seniority variable $\left(\mathrm{X}^{2}=3.16, \mathrm{p}<0.05\right)$. It was found that this significance was in favor of teachers with 1-5 years of professional seniority versus teachers with 5-10 years of professional seniority, in favor of 15-20 years of professional seniority versus teachers with 5-10 years and 10-15 years of professional seniority, and in favor of teachers with 20 or more years versus 5-10 and 10-15 years of professional seniority. 
Table 10. The Kruskal Wallis - H Test Results According to the Variable of Teacher Self-Efficacy Beliefs of Classroom Teachers and the Duration of Use of Computer Technologies

\begin{tabular}{|c|c|c|c|c|c|c|c|}
\hline Dimension & Category & $\mathbf{N}$ & SO & sd & $\mathbf{X}^{2}$ & $\mathbf{p}$ & Difference (LSD) \\
\hline \multirow[t]{5}{*}{ Teacher Self-Efficacy Beliefs } & $1-5$ years & 16 & 608.47 & 4 & 41.59 & .000 & \\
\hline & $5-10$ years & 123 & 459.39 & & & & $\begin{array}{l}\text { 5-10 Years }<15-20 \text { Years } \\
\text { 5-10 Years }<20 \text { Years or } \\
\text { more }\end{array}$ \\
\hline & $10-15$ years & 363 & 533.40 & & & & $\begin{array}{l}10-15 \text { Years }<20 \text { Years or } \\
\text { more }\end{array}$ \\
\hline & $15-20$ years & 404 & 561.42 & & & & $\begin{array}{l}15-20 \text { Years }<20 \text { Years or } \\
\text { more }\end{array}$ \\
\hline & 20 years or more & 221 & 673.98 & & & & \\
\hline
\end{tabular}

According to the test results seen in Table 10, there is a statistically significant difference between the teacher self-efficacy beliefs of classroom teachers and the variable of the duration of the use of computer technologies $\left(\mathrm{X}^{2}=41.59, \mathrm{p}<0.05\right)$. According to the analysis, classroom teachers who had been using computer technologies for 5-10 years had lower self-efficacy beliefs than classroom teachers who had been using computer technologies for 15-20 years and 20 years or more.; classroom teachers who had been using computer technologies for 10-15 years had lower self-efficacy beliefs than classroom teachers who had been using computer technologies for 20 years or more; classroom teachers who had been using computer technologies for 15-20 years had lower self-efficacy beliefs than classroom teachers who had been using computer technologies for more than 20 years.

Table 11. The Kruskal Wallis- H Test Results According to the Variable of Teacher Self-Efficacy Beliefs of Classroom Teachers and the Duration of Use of Mobile Technologies

\begin{tabular}{|c|c|c|c|c|c|c|c|}
\hline Dimension & Category & $\mathbf{N}$ & SO & sd & $\mathbf{X}^{2}$ & $\mathbf{p}$ & Difference (LSD) \\
\hline \multirow[t]{5}{*}{ Teacher Self-Efficacy Beliefs } & $1-5$ years & 79 & 397.48 & 4 & 40.24 & .000 & $\begin{array}{l}1-5 \text { Years }<5-10 \text { Years } \\
1-5 \text { Years }<10-15 \text { Years } \\
1-5 \text { Years }<15-20 \text { Years } \\
1-5 \text { Years }<20 \text { Years or } \\
\text { more }\end{array}$ \\
\hline & $5-10$ years & 297 & 528.82 & & & & $\begin{array}{l}\text { 5-10 Years }<20 \text { Years or } \\
\text { more }\end{array}$ \\
\hline & $10-15$ years & 351 & 578.58 & & & & $\begin{array}{l}10-15 \text { Years }<20 \text { Years or } \\
\text { more }\end{array}$ \\
\hline & $15-20$ years & 276 & 580.94 & & & & $\begin{array}{l}15-20 \text { Years }<20 \text { Years or } \\
\text { more }\end{array}$ \\
\hline & 20 years or more & 124 & 675.37 & & & & \\
\hline
\end{tabular}

According to the results of the Kruskal Wallis - H Test, shown in Table 11, there is a statistically significant difference between classroom teachers' teacher self-efficacy beliefs and the variable of the duration of use of mobile technologies $\left(\mathrm{X}^{2}=40.24, \mathrm{p}<0.05\right)$. It was concluded with the analysis that teachers who had been using mobile technologies for 1-5 years had lower self-efficacy beliefs than the other groups. In addition, teacher self-efficacy belief is in favour of classroom teachers who had been using mobile technologies for 
20 or more years compared to the teachers who had been using mobile technologies for teachers with 5-10 years, 10-15 years, 15-20 years of professional seniority.

\subsubsection{Is there a significant relationship between classroom teachers' TPACK and teacher self-efficacy beliefs?}

Table 12. Pearson Correlation Analysis Between Classroom Teachers' TPACK and Teachers' Self Efficacy Beliefs

\begin{tabular}{llc}
\hline & & Teacher Self-Efficacy Beliefs \\
\hline \multirow{2}{*}{ TPACK } & $\mathrm{r}$ & .76 \\
& $\mathrm{p}$ & .000 \\
\hline
\end{tabular}

The Pearson Correlation Analysis results in Table 11 show that there was a high level of a positive and significant relationship between classroom teaches' TPACK and teacher self-efficacy beliefs $(r=.76$, $\mathrm{p}<0.01$ ). Accordingly, it can be said that as classroom teachers' TPACK increases, teacher self-efficacy beliefs also increase.

\section{Conclusion and Suggestions}

In this study, classroom teachers' TPACK and teacher self-efficacy beliefs were examined according to various variables. 1127 classroom teachers working in public institutions affiliated with Manisa Provincial Directorate of National Education in the 2020-2021 academic year participated in the research.

In the study, it was determined that classroom teachers had a high level of TPACK. It can be concluded that classroom teachers are well-informed as to the use of technology to help students to better comprehend a subject and transfer the content to students in different constructivist ways, and they also have knowledge of how to use technology to teach the conceptual complexities with technology and students to develop new knowledge theories or strengthen the existing ones. The research was conducted during the pandemic and distance education process. It was conducted in a period when teachers taught using technology and technology was constantly used in educational environments. This may have affected the high level of TPACKs of classroom teachers. The literature on the subject supported the results of the research. In his study, Çoklar (2014) determined that teacher candidates had advanced TPACK competencies. Another study that determined teachers' TPACK at an advanced level was conducted by Karalar and Altan (2016). The research result was supported by different studies (Kabakçı Yurdakul, 2011; Çuhadar, Bülbül, \& Ilgaz, 2013; Sezer, 2015; Kula, 2015). However, contrary to these results, Liu, Zhang and Wang (2015) determined that teachers' TPACK was low as a result of their research.

According to the results of the research, classroom teachers' self-efficacy beliefs were at a high level. Accordingly, it can be concluded that classroom teachers believed in their capacity to successfully perform the expected performance at a high level. The literature on the subject was examined and it was observed that the results of the research are supported by similar studies. Coşkun (2019) found that secondary school teachers had a high level of self-efficacy perception. Eker (2014) stated that the self-efficacy belief averages of classroom teachers were at a sufficient level. Duman (2020) examined classroom teachers' self-efficacy perceptions in terms of sub-dimensions and found that classroom teachers' self-efficacy perceptions were at a high level. This result of the research is also supported by other studies (Pendergast \& Garvis, 2011; Sökmen, 2018; Baloğlu, 2020; Shoulders \& Krei, 2015). Contrary to these results, Taşkın and Haciömeroğlu (2010) found in their study that self-efficacy beliefs of prospective classroom teachers were below the average. 
According to the data obtained as a result of the research, the TPACK of the classroom teachers does not show a statistically significant difference according to the gender variable. This result indicates that a teacher being a male or a female is not a determining factor in their TPACK. This result of the research is in parallel to the results of the studies conducted by Akgün and Karadeniz (2013), Gündoğmuş (2013), Hamilton (2013), Çoklar (2014), Kula (2015), Teo and Milutinovic (2015), Karalar and Altan (2016), Kıylık (2016), Akyıldız and Altun (2018), Yüngül (2018) and Çiğilli (2020). Contrary to this result, studies in the literature in which there were significant relationships between the gender variable and TPACK have also been found (Karadeniz \& Vatanartıran, 2015; Lee \& Tsai, 2010; Azgın \& Şenler, 2018).

It was found as a result of the research that the TPACK of the classroom teachers did not show a statistically significant difference according to the professional seniority variable. Professional seniority had not been a factor that will make a difference in teachers' TPACK. This result of the research was also supported by other studies (Burmabiyık, 2014; Azgın \& Şenler, 2018; Y1lmaz, 2020). However, contrary to this result Bal ve Karademir (2013) found in their study that teachers with less professional seniority had higher TPACK levels.

In the study, it was determined that the TPACK of the classroom teachers showed a statistically significant change in terms of the variable of the duration of the use of computer technologies. It can be concluded from the findings that as the duration of the computer to use increases, the TPACK can also increase. This situation was supported by the finding of Kabakçı and Yurdakul (2011) that "an increase in the level of use of information and communication technologies also increases the competencies of TPACK". In addition, this result is compatible with Becker's (2000) inference that "in order for teachers to apply technology to any new teaching strategy, they need to acquire new knowledge about technology and then match it with the demands of the curriculum, classroom". There are other studies in the literature that are compatible with the results of the research. As a result of this study, Kiylik (2016) found significant differences between computer usage experience and TPACK, which are consistent with the results of the research. Karalar and Altan (2016) state that the status of owning a computer is a vital parameter in terms of TPACK.

It was determined in the study that the TPACK of classroom teachers differed statistically significantly in terms of the duration of use of mobile technologies. The high level of TPACK of the teachers who had been using mobile technologies for 20 years or more can be explained by the positive effects of their existing technological knowledge on their TPACK skills. Aky1ldı and Altun (2018) found that classroom teacher candidates who have Internet access thanks to mobile technologies have higher TPACK levels. Contrary to the aforementioned finding, Kiylik (2016) found in his study that mobile technologies do not affect teachers' TPACK.

According to the data obtained as a result of this research, the teacher self-efficacy beliefs of classroom teachers do not show statistically significant differences in terms of the gender variable. Thus, a teacher being a male or a female does not affect teacher self-efficacy beliefs. This situation can be associated with the decrease in the inequalities between men and women day by day. There are studies in the literature that conclude that self-efficacy beliefs do not differ according to gender and that there is no statistically significant relationship between gender and teacher self-efficacy beliefs in accordance with the research results (Savran-Gencer \& Cakiroglu, 2007; Taşkın \& Hacı̈̈meroğlu, 2010; Guo, Justice, Sawyer, \& Tompkins, 2011; Ayra \& Kösterelioğlu, 2016; Güneş, 2016; Özkurt, 2017; Erkoç, 2017; Coşkun, 2019; Şahin, 2019; Elgit, 2020; Y1lmaz, 2020; Duman, 2020). There are also studies supporting the opposite of this finding (Tschannen-Moran \& College, 2011; Yeşilyurt, 2013; Korkut \& Babaoğlan, 2012; Fackler \& Malmberg, 2016; Selçuk, 2016; Baloğlu, 2020).

Another result of this study showed that teachers' self-efficacy beliefs differed significantly according to the variable of professional seniority. In their study, Cheung (2008), Kasap (2012), Altunbaş (2011), Tschannen-Moran and Johnson (2011), Wang, Hall and Rahimi (2015), Güneş (2016), Ayra and 
Kösterelioğlu (2016), Fackler and Malmberg (2016), Kilday, Lenser and Miller (2016), Erkoç (2017), Elgit (2020) and Duman (2020) found results in parallel with the research results.

It was determined that the teacher self-efficacy beliefs of the classroom teachers differed significantly in terms of the variable of the duration of use of the computer technologies. We can deduce that as the duration of teachers' use of computer technology increases, their beliefs about what they can do professionally increase and this affects their self-efficacy. There are limited studies in the literature that examine teacher self-efficacy beliefs according to the duration of use of computer technologies. In their study, Aşkar and Umay (2001) found that there is a positive relationship between the duration of computer use and teachers' self-efficacy beliefs. Kahraman, Yılmaz, Erkol and Yalçın (2013) found in their study that the duration of the use of computer technologies affected teachers' self-efficacy beliefs. The results of the aforementioned studies coincide with the results of the research. It was found in the research that classroom teachers' selfefficacy beliefs differed significantly according to the duration of the use of mobile technologies.

Due to its features such as changing, constantly updating and becoming more functional, mobile technologies may be perceived as complex to some people. The high level of teacher self-efficacy beliefs of classroom teachers who had been using mobile technologies for 20 years or more may be due to their experience since they had been using mobile technologies which had been perceived as complex for a long time. In the literature, no studies in which teachers' self-efficacy beliefs were examined according to the duration of the use of mobile technologies were found. However, in their study, Kwon et al. (2019) stated that teacher self-efficacy for mobile technology predicts technology integration. According to the data obtained as a result of the research, there is a high level of a positive relationship between classroom teachers' self-efficacy beliefs and TPACK. Based on this finding, we can deduce that "there is a relationship between classroom teachers' TPACK and their beliefs in self-efficacy. Studies suggest that self-efficacy beliefs affect the likelihood of a teacher using technology in the classroom (Albion, 1999; Bull, 2009; Abbitt, 2011; Chai, Koh, \& Tsai, 2013). There are other studies in the literature supporting this result of the research in terms of determining the existence of a significant relationship between TPACK and teachers' self-efficacy belief (Gürbüz, 2012; Akgün \& Karadeniz, 2013; Tunçer, 2014; Karakuyu, 2015; Ünal, 2015; Karalar \& Altan, 2016; Çam, 2017; Wright \& Akgündüz, 2018; Martin, 2018; Coşkun, 2019). Contrary to these studies, Karakuyu and Karakuyu (2016) concluded in their study that there is no statistically significant relationship between teachers' self-efficacy beliefs and TPACK. The aforementioned research results support the research in the opposite direction.

In summary, the findings of the study describe classroom teachers' TPACKs and teacher self-efficacy beliefs. Some suggestions that may shed light on future studies on the subject are presented below:

-The quantitative method was used in the research. Different results can be obtained in future studies by using the qualitative method or the mixed method.

-Expanding the demographic variables in the research and revealing the existence of different factors affecting TPACK and teacher self-efficacy beliefs can contribute to the literature.

-Research can be done with academicians working in the faculties of education. The level of TPACKs and self-efficacy beliefs of teacher-trainer academicians can be revealed.

-A more comprehensive study involving teachers from different provinces or countries can be conducted to verify the results of the research.

\section{Acknowledge}

This study was approved by Manisa Celal Bayar University Social and Human Sciences Scientific Research and Publication Ethics Committee with the permission of 2020. 


\section{References}

Abbitt, J. (2011). An Investigation of the Relationship between Self- Efficacy Beliefs about Technology Integration and Technological Pedagogical Content Knowledge (TPACK) among Preservice Teachers. Journal of Digital Learning in Teacher Education, 27(4), 134-143.

Akgün, Ö. E., \& Karadeniz, M. (2013). Sınıf Öğretmenlerinin Teknolojik Pedagojik Alan Bilgilerinin İncelenmesi. IV. Ulusal Lisansüstü Eğitim Sempozyumu (s. 192-199). Sakarya: Sakarya Üniversitesi Eğitim Bilimleri Enstitüsü Yayınları.

Akgün, Ö. E., \& Karadeniz, M. (2013). Sınıf öğretmenlerinin teknolojik pedagojik alan bilgilerinin incelenmesi. Ö. E. İsmail Güleç içinde, VI. Ulusal Lisansüstü Eğitim Sempozyumu Bildiriler Kitabı II (s. 192-199). Sakarya: Sakarya Üniversitesi Eğitim Bilimleri Enstitüsü Yayınları.

Akgündüz, D. (2019). Araştıran Okulda Teknoloji entegrasyonu. M. Yavuz içinde, Araştıran Okul (s. 109111). Konya: Eğitim Yayınevi.

Akkoç, H., \& İmre, S. Y. (2015). Teknolojik Pedagojik Alan Bilgisi. H. Akkoç, \& S. Y. İmre içinde, Teknolojik Pedagojik Alan Bilgisi Temelli Olasılık ve İstatistik Öğretimi. Ankara: PEGEM.

Akyıldız, S., \& Altun, T. (2018). Examining Technological Pedagogical and Content Knowledge (TPACK) Levels of Primary Pre-Service Teachers Based on Some Variables. Trakya Üniversitesi Ĕ̈itim Fakültesi Dergisi, 8(2), 318-333.

Albion, P. (1999). Self-efficacy beliefs as an indicator of teachers' preparedness for teaching with technology. J. Price, J. Willis, D. A. Willis, M. Jost, \& S. B.-M. (Eds.) içinde, Proceedings of the Society for Information Technology \& Teacher Education International Conference 1999 (s. 16021608). Waynesville, NC, USA: AACE.

Angeli, C., \& Valanides, N. (2005). Preservice elementary teachers as information and communication technology designers: An instructional systems design model based on an expanded view of pedagogical content knowledge. Journal of Computer Assisted Learning, 21(4), 292-302.

Arslan, S., \& Şendurur, P. (2017). Eğitimde Teknoloji Entegrasyonunu Etkileyen Faktörlerdeki Değişim. Mehmet Akif Ersoy Üniversitesi Eğitim Fakültesi Dergisi(43), 25-50.

Aslan, M., \& Kalkan, H. (2018). Öğretmen Öz Yeterlik Algılarının Analizi. Bingöl Üniversitesi Sosyal Bilimler Enstitüsü Dergisi, 8(16), 477-493.

Aşkar, P., \& Umay, A. (2001). İlköğretim Matematik Öğretmenliği Öğrencilerinin Bilgisayarla İlgili Öz Yeterlik Algısı. Hacettepe Üniversitesi Eğitim Fakültesi Dergisi, 21, 1-8.

Ayra, M., \& Kösterelioğlu, İ. (2016). Öğretmenlerin Mesleki Öz-Yeterlik İnançlarının Çeşitli Değişkenler Açısından İncelenmesi. Gumushane Universitesi Sosyal Bilimler Enstitüsü Elektronik Dergisi, 7(17), 81-101.

Azgın, A. O., \& Şenler, B. (2018). Investigating the Technological Pedagogical Content Knowledge of Primary Teachers. Journal of Computer and Education Research, 6(11), 47-66.

Bal, M. S., \& Karademir, N. (2013). Sosyal Bilgiler Öğretmenlerinin Teknolojik Pedagojik Alan Bilgisi (TPAB) Konusunda Öz-Değerlendirme Seviyelerinin Belirlenmesi. Pamukkale Üniversitesi Ĕgitim Fakültesi Dergisi(34), 15-32.

Baloğlu, C. (2020). Sınıf Öğretmenlerinin Öz Yeterlilik İnançlarl ile Örgütsel Yaratıcılık Düzeyleri Arasındaki İlişki (Kütahya Merkez İlçesi Örneği). (Yayımlanmamış Yüksek Lisans Tezi), Adanan Menderes Üniversitesi Sosyal Bilimler Enstitüsü, Aydın. 
Bandura, A. (1977). Self-Efficacy: Toward a Unifying Theory of Behavioural Change. Psychological Review, 84(2), 191-215.

Becker, H. (2000). Findings from the Teaching, Learning, and Computing Survey: Is Larry Cuban Right? Education Policy Analysis Archives, 8(51).

Bilici, S. C., \& Yadigaroğlu, M. (2018). Kuram ve Uygulamada Teknolojik Pedagojik Alan Bilgisi. Ş. U. Sağır içinde, Teoriden Uygulamaya Pedagojik Alan Bilgisi (s. 124-153). Ankara: Pegem.

Bull, P. (2009). Self-Efficacy and Technology Integration: Perceptions of First Year Teaching Fellows to Technology Integration in Education. I. Gibson, R. Weber, K. McFerrin, R. Carlsen, \& D. Willis içinde, Society for Information Technology \& Teacher Education International Conference 2009 (s. 1768-1776). Charleston, SC, USA: AACE.

Burmabıyık, Ö. (2014). Öğretmenlerin Teknolojik Pedagojik İçerik Bilgilerine Yönelik Öz-Yeterlilik Algılarının Çeşitli Değişkenler Açısından Incelenmesi (Yalova İli Örneği). (Yayımlanmamış Yüksek Lisans Tezi), Sakarya Üniversitesi, Sakarya.

Büyüköztürk, Y., Çakmak, E., Akgün, Ö. E., Karadeniz, Ş., \& Demirel, F. (2020). Bilimsel Araştırmanın Temelleri. Ankara: Pegem.

Chai, C. S., Koh, J. H., \& Tsai, C. C. (2013). A Review of Technological Pedagogical Content Knowledge. Educational Technology \& Society, 16(2), 31-51.

Cheung, H. Y. (2008). Teacher efficacy: a comparative study of Hong Kong and Shanghai primary inservice teachers. The Australian Educational Researcher, 35, 103-123.

Coşkun, N. (2019). Ortä̈ğretim Öğretmenlerinin Teknolojik Pedagojik Alan Bilgisi Düzeyleri ile Ögretmen Öz Yeterlik Algıları Arasındaki İlişkinin İncelenmesi. (Yayımlanmamış Yüksek Lisans Tezi), Karamanoğlu Mehmetbey Üniversitesi Fen Bilimleri Enstitüsü, Karaman.

Çam, E. (2017). İlköğretim Öğretmenlerinin Teknolojik Pedagojik Alan Bilgisi (TPAB) Düzeylerinin Yaşam Boyu Öğrenme, Özyeterlik Düzeyleri ve Hizmet Iç̧i Ĕgitim Gereksinimleri Açısından İncelenmesi: Muşs/Bulanık Örneği. (Yayımlanmamış Yüksek Lisans Tezi), Amasya Üniversitesi Sosyal Bilimler Enstitüsü, Amasya.

Çelebi, N. (2016). Küreselleşmeye Genel Bir Bakış. N. Çelebi içinde, Küreselleşme ve Eğitime Yansimalart. Ankara: Nobel.

Çiğilli, E. (2020). Sını Öğretmenlerinin Teknolojik Pedagojik Alan Bilgisi ile 21. Yüzyıl Öğreten Becerileri Algı Düzeyleri Arasındaki İlişkinin İncelenmesi. (Yayımlanmamış Yüksek Lisans Tezi), Çanakkale.

Çoklar, A. N. (2014). Sınıf Öğretmenliği Öğretmen Adaylarının Teknolojik Pedagojik İçerik Bilgisi Yeterliklerinin Cinsiyet ve BİT Kullanım Aşamaları Bağlamında İncelenmesi. Eğitim ve Bilim, 39(175), 319-330.

Çolak, İ. Yorulmaz, Y. İ., \& Altınkurt, Y. (2017, Haziran). Öğretmen Özyeterlik İnancı Ölçeği Geçerlik ve Güvenirlik Çalışması. MSKU Eğitim Fakültesi Dergisi, 4(1).

Çuhadar, C., Bülbül, T., \& Ilgaz, G. (2013). Öğretmen adaylarının bireysel yenilikçilik özellikleri ile TPAB yeterlikleri arasındaki ilişkinin incelenmesi. İlköğretim Online, 12(3), 797-807.

Değirmenci, H. (2014). İlk Okuma Öğretimi ve Teknoloji. İ. S. Erdem içinde, Okuma Yazma Eğitimi ve Teknoloji (Cilt 1, s. 29-48). Ankara: NOBEL Yayınc1lik.

Duman, Ü. (2020). Sinıf Öğretmenlerinin Öz Yeterlik Algılart ile Sinıf İçi Ders Işsleme Sürecindeki Soru Sorma Teknikleri Arasındaki İlişkinin İncelenmesi. (Yayımlanmamış Yüksek Lisans Tezi), İstanbul: Marmara Üniversitesi Temel Eğitim Anabilim Dalı, İstanbul. 
Eker, C. (2014). Sınıf Öğretmenlerinin Öz-Yeterlik İnanç Düzeyleri Üzerine Bir Araştırma. Uşak Üniversitesi Sosyal Bilimler Dergisi, 7(1), 162-178.

Elgit, B. (2020). Sınıf Öğretmenlerinin Öz Yeterlik İnançları ile Sınıf İçi Davranışlarının İncelenmesi. (Yayımlanmamış Yüksek Lisans Tezi), Adana.

Ertmer, P. (2005). Teacher pedagogical beliefs: The final frontier in our quest for technology integration. Educational Technology Research and Development, 53, 25-39.

Erkoç, K. (2017). Sınıf Öğretmenlerinin Öz Yeterlik Algıları ile Problem Çözme Becerileri Arasındaki Illişkinin İncelenmesi. (Yayımlanmamış Yüksek Lisans Tezi), Atatürk Üniversitesi Eğitim Bilimleri Enstitüsü, Erzurum.

Fackler, S., \& Malmberg, L. E. (2016). Teachers' self-efficacy in 14 OECD countries: Teacher, student group, school and leadership effects. Teaching and Teacher Education, 56, 185-195.

Guo, Y., Justice, L. M., Sawyer, B., \& Tompkins, V. (2011). Exploring factors related to preschool teachers' self-efficacy. Teaching and Teacher Education, 27(5), 961-968.

Gündoğmuş, N. (2013). Öğretmen Adaylarının Teknolojik Pedagojik Alan Bilgileri ile Öğrenme Stratejileri Arasındaki İlişkinin İncelenmesi. (Yayımlanmamış Yüksek Lisans Tezi), Necmettin Erbakan Üniversitesi, Konya.

Güneş, A. M. (2016). Sınıf Öğretmenlerinin Sınıf Yönetim Becerileri, Teknoloji Kullanımları ve Öz Yeterlik Inançları Arasındaki İlişki. (Yayımlanmamış Doktora Tezi), Gazi Üniversitesi Eğitim Bilimleri Enstitüsü, Ankara.

Gürbüz, E. (2012). Fen Bilimleri Öğretmen Adaylarının Teknolojik Pedagojik Alan Bilgilerindeki ve Ögretmen Öz Yeterlik Inançlarındaki Değişimlerin İncelenmesi. (Yayımlanmamış Yüksek Lisans Tezi), İstanbul Üniversitesi Eğitim Bilimleri Enstitüsü, İstanbul.

Hamilton, C. (2013). An Investigation into the Relationships Between the Technological Pedagogical Content Knowledge of University Teacher Education Faculty and Their Age, Rank, and Gender. (Unpublished Doctoral Dissertation), University of North Texas, Texas.

Kaçar, T., \& Beycioğlu, K. (2017). İlköğretim Öğretmenlerinin Öz Yeterlik İnançlarının Çeşitli Değişkenler Açısından İncelenmesi. Elementary Education Online, 16(4), 1753-1767.

Kabakçı Yurdakul, I. (2011). Öğretmen adaylarının TPAB yeterliklerinin bilgi ve iletişim teknolojilerini kullanımları açısından incelenmesi. Hacettepe Üniversitesi Journal of Education, 40, 397-408.

Kahraman, S., Yılmaz, Z. A., Erkol, M., \& Yalçın, S. A. (2013). Investigation of Pre-service Teachers' Self-Efficacy Beliefs of Educational Internet Use. Elementary Education Online, 12(4), 1000-1015.

Kandemir, M. (2015). Öz Yeterlik. B. E. Tekin, \& Ş. I. Terzi içinde, Eğitimde Pozitif Psikoloji Uygulamaları (s. 39-74). Ankara: PEGEM.

Karadeniz, Ş., \& Vatanartıran, S. (2015). Primary School Teachers' Technological Pedagogical Content Knowledge. Elementary Education Online, 14(3), 1071-1028.

Karakuyu, A. (2015). Bazı Değişkenlerin İlköğretim Sınıf Öğretmenlerinin Teknolojik Pedagojik Alan Bilgilerine Katkılarının İncelenmesi. (Yayımlanmamış Yüksek Lisans Tezi), Mustafa Kemal Üniversitesi Sosyal Bilimler Enstitüsü Anabilim Dalı, Hatay.

Karakuyu, Y., \& Karakuyu, A. (2016). Motivasyon ve Öz Yeterliğin Sınıf Öğretmeni Adaylarının Teknolojik Pedagojik Alan Bilgilerine Katkısı. Uşak Üniversitesi Eğitim Araştırmaları Dergisi, 2(1), 89-100. 
Karalar, H., \& Altan, B. A. (2016). Sınıf Öğretmeni Adaylarının Teknolojik Pedagojik Alan Bilgisi Yeterliklerin ve Öğretmen Özyeterliklerinin İncelenmesi. Cumhuriyet International Journal of Education, 5(USOS Özel Say1), 15-30.

Karasar, N. (2008). Bilimsel Araştırma Yöntemleri. Ankara: Nobel Yayın Dağıtım.

Kaya, S., \& Dağ, F. (2013). Sınıf Öğretmenlerine Yönelik Teknolojik Pedagojik İçerik Bilgisi Ölçeği’nin Türkçeye Uyarlanması. Kuram ve Uygulamada Eğitim Bilimleri, 13(1), 291-306.

Kilday, J. E., Lenser, M. L., \& Miller, A. D. (2016). Considering students in teachers' self-efficacy: Examination of a scale for student-oriented teaching. Teaching and Teacher Education, 56, 61-71.

Klassen, R. M. (2009). Exploring the Validity of a Teachers' Self-Efficacy Scale in Five Countries. Contemporary Educational Psychology, 34(1), 67-76.

Klassen, R. M., \& Tze, V. M. (2014). Teachers' Self-Efficacy, Personality and Teaching Effectiveness: A Meta-Analysis. Educational Research Review, 12, 59-76.

Kıylık, D. (2016). Sınıf Öğretmeni Adaylarının Teknolojik Pedagojik Alan Bilgisi Düzeylerinin Çeşitli Değişkenler Açısından Incelenmesi. (Yayımlanmamış Yüksek Lisans Tezi), Yüzüncü Yıl Üniversitesi, Van.

Koç, H., \& Bursal, M. (2016). Öz Yeterlik: Bir Kavram Analizi. International Periodical for the Languages, Literature and History of Turkish or Turkic, 19(11), 63-80.

Koehler, M. J., \& Mishra, P. (2008). Introducing TPCK. A. C. (Ed.) içinde, The handbook of technological pedagogical content knowledge (TPCK) for educators (s. 3-29). Mahwah, NJ: Lawrence Erlbaum Associates.

Koehler, M. J., Mishra, P., Akçaoğlu, M., \& Rosenberg, J. M. (2013). The Technological Pedagogical Content Knowledge Framework for Teachers and Teachers Educators. ICT Integrated Teacher Education: A Resource Book, 1-8.

Korkut, K., \& Babaoğlan, E. (2012). Sınıf Öğretmenlerinin Öz Yeterlik İnançları. Uluslararası Yönetim Iktisat ve Işsletme Dergisi, 8(16), 270-282.

Kula, A. (2015). Öğretmen adaylarının teknolojik pedagojik alan bilgisi (TPAB) yeterliliklerinin incelenmesi: Bartın üniversitesi örneği. Akademik Sosyal Araştırmalar Dergisi, 3(2), 395-412.

Kwon, K., Ottenbreit-Leftwich, A. T., Sari, A. R., Khlaif, Z., Zhu, M., Nadir, H., \& Gök, F. (2019). Teachers' Self-efficacy Matters: Exploring the Integration of Mobile Computing Device in Middle Schools. TechTrends, 63, 682-692.

Lee, M. H., \& Tsai, C. C. (2010). Exploring teachers' perceived self-efficacy and technological pedagogical content knowledge with respect to educational use of the World Wide Web. Instr Sci, 38, 1-21.

Liu, Q., Zhang, S., \& Wang, Q. (2015). Surveying Chinese In-Service K12 Teachers' Technology, Pedagogy, and Content Knowledge. Journal of Educational Computing Research, 55(1), 55-74.

Martin, C. L. (2018). Correlational Analysis of Self-efficacy and Technological Pedagogical Content Knowledge of Board-Certified Teachers. (Unpublished Doctoral Dissertation), Grand Canyon University, Arizona.

MEB. (2018). 2023 Ĕ̆itim Vizyonu. 09.02.2021 tarihinde 2023 Eğitim Vizyonu: http://2023vizyonu.meb.gov.tr/doc/2023_EGITIM_VIZYONU.pdf adresinden alındı

Mishra, P., \& Koehler, M. (2009). What is technological pedagogical content knowledge? Contemporary Issues in Technology and Teacher Education, 9(1), 60-70. 
Mishra, P., \& Koehler, M. J. (2006). Technological Pedagogical Content Knowledge: A Framework for Teacher Knowledge. Teachers College Record, 108(6), 1017-1054.

Mishra, P., \& Koehler, M. J. (2006, June). Technological Pedagogical Content Knowledge: A Framework for Teacher Knowledge. Teachers College Record, 108(6), 1017-1054.

Önal, N. (2019). Öğretimde Kullanılabilecek Teknoloji Destekli Uygulamalar: Kelime Bulutu Oluşturma Araçları. N. Önal içinde, Ĕgitimde Teknoloji Uygulamaları (s. 2-14). Ankara: PEGEM.

ÖYGM. (2017). Öğretmenlik Mesleği Genel Yeterlikleri. 30.03.2021 tarihinde Öğretmen Yetiştirme ve Geliştime Genel Müdürlüğü: http://oygm.meb.gov.tr/meb_iys_dosyalar/2017_12/11115355_YYRETMENLYK_MESLEYY_G ENEL_YETERLYKLERY.pdf adresinden alındı

Pendergast, D., \& Garvis, S. K. (2011). Pre-Service Student Teacher Self-Efficacy Beliefs: An Insight in to the Making of Teachers. Australian Journal of Teacher Education, 36(12), 46-58.

Savran-Gencer, A., \& Cakiroglu, J. (2007). Turkish reservice science teachers' efficacy beliefs regarding science teaching and their beliefs about classroom management. Teaching and Teacher Education, 23(5), 664-675.

Selçuk, G. (2016). Öğretmen Adaylarının Yaşam Boyu Öğrenme Yeterlik Algıları ve Öz-Yeterlik Inançlarının Ögretmen Yetiştirme Programı Kapsamında İncelenmesi. (Yayımlanmamış Doktora Tezi), Yakın Doğu Üniversitesi Eğitim Bilimleri Enstitüsü, Lefkoşa.

Sezer, B. (2015). Examining techno pedagogical knowledge competencies of teachers in terms of some variables. Procedia - Social and Behavioural Sciences, 174, 208-215.

Shoulders, T. L., \& Krei, M. S. (2015). Rural High School Teachers' Self-Efficacy İn Student Engagement, İnstructional Strategies and Classroom Management. American Secondary Education, 44(1), 50-61.

Shulman, L. (1986, February). Those who understand: Knowledge growth in teaching. Educational Researcher, 15(2), 4-14.

Shulman, L. (1987). Knowledge and Teaching: Foundations of the New Reform. Harvard Educational Review, 57(1), 1-22.

Sökmen, Y. (2018). Sinıf Öğretmenlerinin Öz-yeterlik, Özerklik, İs Memnuniyeti, Öğretmen Katılımı ve Tükenmişliği Arasındaki İlişki: Bir Model Geliştirme Çalışması. (Yayımlanmamış Doktora Tezi), Atatürk Üniversitesi Eğitim Bilimleri Enstitüsü, Erzurum.

Şahin, B. (2019). Sınıf Öğretmenlerinin Öz Yeterlik Inançlarl, Mesleğe Yönelik Tutumları ve Yaşam Doyumlarının Incelenmesi. (Yayımlanmamış Yüksek Lisans Tezi), Mehmet Akif Ersoy Üniversitesi Eğitim Bilimleri Enstitüsü, Burdur.

Taşkın, Ç. Ş., \& Hacıömeroğlu, G. (2010). Sınıf Öğretmeni Adaylarının Öz Yeterlik İnançları: Nicel ve Nitel Verilere Dayalı Bir İnceleme. İnönü Üniversitesi Eğitim Fakültesi Dergisi, 11(1), 21-40.

Teo, T., \& Milutinovic, V. (2015). Modelling the intention to use technology for teaching mathematics among pre-service teachers in Serbia. Australasian Journal of Educational Technology, 31(4), 363380.

Tschannen-Moran, M., \& Johnson, D. (2011). Exploring literacy teachers' self-efficacy beliefs: Potential sources at play. Teaching and Teacher Education, 27(4), 751-761.

Tschannen-Moran, M., Hoy, A. W., \& Hoy, W. K. (1998). Teacher Efficacy: Its Meaning and Measure. Review of Educational Research, 68(2), 202-248. 
Tunçer, M. (2014). Türk Ingilizce Öğretmen Adaylarının Teknolojik Pedagojik Alan Bilgileri ile Ögretmenlik Öz yeterlikleri Arasındaki İlişki. (Yayımlanmamış Yüksek Lisans Tezi), İstanbul Üniversitesi Eğitim Bilimleri Enstitüsü, İstanbul.

Ünal, M. (2015). Öğretmen Adaylarının Teknolojik Pedagojik Alan Bilgilerinin ve Öğretmen Öz Yeterlik Algılarının İncelenmesi. (Yayımlanmamış Yüksek Lisans Tezi), Gazi Üniversitesi Eğitim Bilimleri Enstitüsü, Ankara.

Wang, H., Hall, N. C., \& Rahimi, S. (2015). Self-efficacy and causal attributions in teachers: Effects on burnout, job satisfaction, illness, and quitting intentions. Teaching and Teacher Education, 47, 120130.

Willermark, S. (2018). Technological Pedagogical and Content Knowledge: A Review of Empirical Studies Published From 2011 to 2016. Journal of Educational Computing Research, 56(3), 315-343.

Wright, B., \& Akgündüz, D. (2018). The relationship between technological pedagogical content knowledge (TPACK) self-efficacy belief levels and the usage of Web 2.0 applications of pre-service science teachers. World Journal on Educational Technology: Current Issues, 10(1), 52-69.

Yeşilyurt, E. (2013). Öğretmen Adaylarının Öğretmen Öz Yeterlik Algıları. Elektronik Sosyal Bilimler Dergisi, 12(45), 88104.

Yılmaz, M. U. (2020). Sını Öğretmenlerinin Teknolojik Pedagojik Alan Bilgisi ile Mesleki Profesyonelliği Arasındaki İlişkinin İncelenmesi. (Yayımlanmamış Yüksek Lisans Tezi), Çukurova Üniversitesi Sosyal Bilimler Enstitüsü, Adana.

Yılmaz, G. K. (2015). Türkiye'deki Teknolojik Pedagojik Alan Bilgisi Çalışmalarının Analizi: Bir MetaSentez Çalışması. Eğitim ve Bilim, 40(178), 103-122.

Yılmaz, M., Köseoğlu, P., Gerçek, C., \& Soran, H. (2004). Öğretmen Öz Yeterlik İnancı. Bilim ve Aklın Aydınlı̆̆ında Ĕ̈itim Dergisi, 5(58), 50-54.

Yüngül, Y. (2018). Sinıf Öğretmeni Adaylarının Teknolojik Pedagojik Alan Bilgisi Yeterlilikleri ile Teknoloji Kullanım Niyetleri Arasındaki İlişkinin İncelenmesi. (Yayımlanmamış Yüksek Lisans Tezi), Marmara Üniversitesi Eğitim Bilimleri Enstitüsü, İstanbul.

Zimmerman, B. J. (2000). Self-Efficacy: An Essential Motive to Learn. Contemporary Educational Psychology, 25, 82-91. 